\title{
Existence and Virulence Designation of Listeria Monocytogenes in Retail Chilled Pork Byproducts in Cairo Porcine Markets with Trials of Using Lactobacillus Probiotic as Anti-Listerial Meat Perservative
}

\author{
Azza S.M. Abuelnaga, Nagwa S. Atta, Riham M. Hedia, E. A. Elgabry, Eman \\ S. Ibrahim, Amr M. Abdou, M. A. Bakry, Sohier M. Syame, \\ Dalia M. Sedeek and A.S. Hakim* \\ Department of Microbiology and Immunology, National Research Centre, 33 Bohouth st., Dokki, Cairo, Egypt
}

\begin{abstract}
Background: It is well known that Listeria monocytogenes is a substantial foodborne pathogen that can boost in cooling temperature and causes serious human infections.

Materials and methods: The study investigated 60 chilled pork byproducts purchased from Egyptian markets and PCR assayed for the presence of certain virulence genes answerable for the pathogenicity, besides the antilisterial activity inquiry of probiotic bacteria.

Results: eleven Listeria monocytogenes isolates (18.3\%) were obtained and the survey exposed that 6 isolates harbored hly gene, 7 carried inlA gene, and 7 loaded prfA gene in incidence of 54.5, 63.6, and 63.6\% respectively in which the three genes were identified in three isolates (27.3\%). The isolates were sensitive to Lactobacillus acidophilus more than Lactobacillus plantarum even diluted to $10^{-5}$.

Conclusion: The study revealed there were a considerable isolation percent of Listeria monocytogenes with their virulence genes in Egyptian pork byproducts. Probiotic bacteria can combat the microbe as modern and safe protection.
\end{abstract}

Keywords: Listeria monocytogenes- pork byproducts- virulence genes- Lactobacillus

\section{Introduction}

Listeria monocytogenes (L. monocytogenes) represents a Gram-positive, facultative intracellular, rodshaped bacteria, exist in a different environments, including soil, water, and foods. L. monocytogenes has become perceived as a substantial opportunistic human foodborne pathogen, being tolerant to acidic $\mathrm{pH}$, low temperature and high salt conditions [1]. However, in good healthy people, human listeriosis often shows non specific flu-like signs and gastroenteritis, sometimes, the disease can evolve into septicaemia, meningitis, encephalitis, stillbirth, abortion and, may lead to death in immuno-compromised people, pregnant women and inappropriate antibiotic treatment [2]. Certainly, invasive listeriosis is a public health concern due mainly to its high fatality rate; $20-30 \%$, which far overrides other common foodborne pathogens [3].

The pathogenicity and capability of $L$. Monocytogenes to induce these disease criteria is depending on its virulence proteins encoded by what is called a virulence gene cluster. L. monocytogenes adheres to and is internalized by host cells with the assistance of a family of surface proteins called internalins; InlA and InlB. InlA (an $88 \mathrm{kDa}$ protein encoded by inlA) mediate L. monocytogenes entry into epithelial cells, while, InlB (a 65 $\mathrm{kDa}$ protein encoded by inlB) facilitate $L$. monocytogenes entry into a much wider scope of host-cell types. Gaining entry into host cells enables $L$. monocytogenes to bypass host immune oversight roles [4].

Following its host cell's entrance, $L$. monocytogenes is originally existed in single-membrane vacuoles, the virulence associated molecule which responsible for digest those primary vacuoles, subsequent escape and extensively multiplication; is called listeriolysin O (LLO) (a $58 \mathrm{kDa}$ protein encoded by $h l y \mathrm{~A}$ ) which is a poreforming toxin that is considered an essential for L. monocytogenes virulence [5]. Moreover, prfA gene encodes PrfA (a $27 \mathrm{kDa}$ protein) which activates the transcription of many L. monocytogenes virulence-associated genes and considered a pleiotropic virulence regulator [6]. A major concept of public health and regulatory authorities is to control pathogenic microorganisms in food and improve safety, this could be achieved through accurate and rapid determination of the pathogenic potential L. monocytogenes isolates to limit its spread and reduce the food intoxication probability. The implementation of molecular techniques has eased the identification and characterization of main virulence-associated genes and proteins in L. monocytogenes [7]. The aims of this work were to assess the prevalence of $L$. monocytogenes in chilled pork and pork byproducts in Cairo porcine markets, Egypt, and evaluate the isolates public health through checking some virulence determinants, in addition to alternative combating trials of the organism using probiotic bacteria. 


\section{Materials And Method}

A total number of 60 chilled pork and pork by-products samples, purchased from Cairo porcine retail markets. Samples were double-bagged at ice box,transferred to the laboratory, chopped into small pieces, and 5 $\mathrm{g}$ from each sample was transferred to $45 \mathrm{ml}$ of $1 \%$ buffered peptone-water and incubated for $24 \mathrm{~h}$ at $30^{\circ} \mathrm{C}$. Listeria species were isolated in accordance to ISO 11290-1, 2004. A portion of $0.1 \mathrm{ml}$ of primary enrichments was transferred to $10 \mathrm{ml}$ of buffered Listeria enrichment broth with Listeria selective enrichment supplement (with cicloeximide) (Oxoid) and incubated at $30{ }^{\circ} \mathrm{C}$ for $24 \mathrm{~h}$. Secondary enrichments were streaked to Palcam agar with Palcam selective supplement (Oxoid) and incubated for $24 \mathrm{~h}$ at $37^{\circ} \mathrm{C}$. The suspected typical grayishgreen glistening pin point colonies of surrounded by a diffuse black zone of aesculin hydrolysis were presumptively identified as Listeria spp. Gram-positive colonies were tested for haemolysis on blood agar (Columbia blood agar Oxoid), catalase (Bactident catalase Merk) and species identification was made with API Listeria kit (BioMerieux).

\subsection{Anti listerial bioperservation:}

Lactobacillus acidophilus (ATCC 4356) and Lactobacillus plantarum (ATCC 8014) were obtained from the reference laboratory of the Cairo Microbiological Resources Center (Cairo MIRCEN), Faculty of Agriculture, Ain-Shams University and reactivated and propagated using suitable cultures and the level of inoculum chosen to give an initial load of approximately $10^{6} \mathrm{cfu} / \mathrm{ml}$ in inoculated samples [8].

\subsection{Antimicrobial assay:}

The inhibitory activity of two different Lactobacillus strains was screened against L. monocytogenes at refrigeration temperatures in laboratory media using conventional agar spot test in triplicate as described [9]. The anti listerial activity was determined by measuring the clear or translucent zone around the colonies, considering a diameter of $0.5 \mathrm{~mm}$ or greater inhibitory toward the pathogen. The total number of $L$. monocytogenes present was determined by using the pour plate method [10].

\subsection{DNA extraction:}

DNA extraction from the samples was performed using the QIAamp DNA Mini kit (Qiagen, Germany, $\mathrm{GmbH}$ ) with modifications from the manufacturer's recommendations. Briefly, $200 \mu 1$ of the sample suspension was incubated with $20 \mu \mathrm{l}$ of proteinase $\mathrm{K}$ and $200 \mu \mathrm{l}$ of lysis buffer at $56^{\circ} \mathrm{C}$ for $10 \mathrm{~min}$. After incubation, $200 \mu \mathrm{l}$ of $100 \%$ ethanol was added to the lysate. The sample was then washed and centrifuged following the manufacturer's recommendations. Nucleic acid was eluted with $100 \mu \mathrm{l}$ of elution buffer provided in the kit.

\subsection{Oligonucleotide Primer: Primers used were supplied from Metabion (Germany) are listed in table (1). 2.5. PCR amplification:}

For either $h l y A$ or prfA uniplex PCR, primers were utilized in a $25 \mu 1$ reaction containing $12.5 \mu 1$ of EmeraldAmp Max PCR Master Mix (Takara, Japan), $1 \mu \mathrm{l}$ of each primer of 20 pmol concentration, $4.5 \mu \mathrm{l}$ of water, and $6 \mu 1$ of DNA template. For inlA and inlB duplex PCR, primers were utilized in a 50- $\mu 1$ reaction containing $25 \mu \mathrm{l}$ of EmeraldAmp Max PCR Master Mix (Takara, Japan), $1 \mu 1$ of each primer of 20 pmol concentration, $13 \mu \mathrm{l}$ of water, and $8 \mu \mathrm{l}$ of DNA template. The reaction was performed in an Applied biosystem 2720 thermal cycler.

2.6. Analysis of the PCR Products: The products of PCR were separated by electrophoresis on $1.5 \%$ agarose gel (Applichem, Germany, GmbH) in 1x TBE buffer at room temperature using gradients of $5 \mathrm{~V} / \mathrm{cm}$. For gel analysis, $20 \mu \mathrm{l}$ of the products was loaded in each gel slot. Gelpilot $100 \mathrm{bp}$ plus Ladder (Qiagen, Germany, $\mathrm{GmbH})$ and a Gene ruler $100 \mathrm{bp}$ ladder (Fermentas) were used to determine the fragment sizes. The gel was photographed by a gel documentation system (Alpha Innotech, Biometra) and the data were analyzed through computer software.

Table (1): Primers sequences, target genes, amplicon sizes and cycling conditions.

\begin{tabular}{|c|c|c|c|c|c|c|c|c|}
\hline \multirow{2}{*}{$\begin{array}{l}\text { Target } \\
\text { gene }\end{array}$} & \multirow[t]{2}{*}{ Primers sequences } & \multirow{2}{*}{$\begin{array}{l}\text { Amplified } \\
\text { segment } \\
\text { (bp) }\end{array}$} & \multirow{2}{*}{$\begin{array}{l}\text { Primary } \\
\text { denaturat } \\
\text { ion }\end{array}$} & \multicolumn{3}{|c|}{ Amplification (35 cycles) } & \multirow{2}{*}{$\begin{array}{l}\text { Final } \\
\text { extension }\end{array}$} & \multirow[t]{2}{*}{ Reference } \\
\hline & & & & $\begin{array}{l}\text { Secondar } \\
\text { denaturation }\end{array}$ & Annealing & Extension & & \\
\hline \multirow[t]{2}{*}{$p r f A$} & $\begin{array}{l}\text { TCT-CCG-AGC-AAC- } \\
\text { CTC-GGA-ACC }\end{array}$ & \multirow[t]{2}{*}{1052} & \multirow[t]{2}{*}{$\begin{array}{l}94^{\circ} \mathrm{C} \\
5 \mathrm{~min}\end{array}$} & \multirow[t]{2}{*}{$\begin{array}{l}94^{\circ} \mathrm{C} \\
30 \mathrm{sec} .\end{array}$} & \multirow[t]{2}{*}{$\begin{array}{l}50^{\circ} \mathrm{C} \\
1 \mathrm{~min} .\end{array}$} & \multirow[t]{2}{*}{$\begin{array}{l}72^{\circ} \mathrm{C} \\
1 \mathrm{~min} .\end{array}$} & \multirow[t]{2}{*}{$\begin{array}{l}72^{\circ} \mathrm{C} \\
10 \mathrm{~min} .\end{array}$} & \multirow[t]{2}{*}{ [11] } \\
\hline & $\begin{array}{l}\text { TGG-ATT-GAC-AAA- } \\
\text { ATG-GAA-CA }\end{array}$ & & & & & & & \\
\hline \multirow[t]{2}{*}{ inlA } & $\begin{array}{l}\text { ACG AGT AAC GGG } \\
\text { ACA AAT GC }\end{array}$ & \multirow[t]{2}{*}{800} & \multirow[t]{2}{*}{$\begin{array}{l}94^{\circ} \mathrm{C} \\
5 \mathrm{~min} .\end{array}$} & \multirow[t]{2}{*}{$\begin{array}{l}94^{\circ} \mathrm{C} \\
30 \mathrm{sec} .\end{array}$} & \multirow[t]{2}{*}{$\begin{array}{l}55^{\circ} \mathrm{C} \\
45 \mathrm{sec} .\end{array}$} & \multirow[t]{2}{*}{$\begin{array}{l}72^{\circ} \mathrm{C} \\
30 \mathrm{sec}\end{array}$} & \multirow[t]{2}{*}{$\begin{array}{l}72^{\circ} \mathrm{C} \\
10 \text { min. }\end{array}$} & \multirow[t]{2}{*}{ [6] } \\
\hline & $\begin{array}{l}\text { CCC GAC AGT GGT } \\
\text { GCT AGA TT }\end{array}$ & & & & & & & \\
\hline
\end{tabular}




\begin{tabular}{|c|c|c|c|c|c|c|c|c|}
\hline inlB & $\begin{array}{l}\text { CTGGAAAGTTTGTA } \\
\text { TTTGGGAAA } \\
\text { TTTCATAATCGCCAT } \\
\text { CATCACT }\end{array}$ & 343 & $\begin{array}{l}94^{\circ} \mathrm{C} \\
5 \mathrm{~min} .\end{array}$ & $\begin{array}{l}94^{\circ} \mathrm{C} \\
30 \mathrm{sec} .\end{array}$ & $\begin{array}{l}55^{\circ} \mathrm{C} \\
45 \mathrm{sec} .\end{array}$ & $\begin{array}{l}72^{\circ} \mathrm{C} \\
30 \mathrm{sec} .\end{array}$ & $\begin{array}{l}72^{\circ} \mathrm{C} \\
10 \mathrm{~min} .\end{array}$ & [7] \\
\hline hly & $\begin{array}{l}\text { GCA-TCT-GCA-TTC- } \\
\text { AAT-AAA-GA } \\
\text { TGT-CAC-TGC-ATC- } \\
\text { TCC-GTG-GT }\end{array}$ & 174 & $\begin{array}{l}94^{\circ} \mathrm{C} \\
5 \mathrm{~min} .\end{array}$ & $\begin{array}{l}94^{\circ} \mathrm{C} \\
30 \mathrm{sec} .\end{array}$ & $\begin{array}{l}50^{\circ} \mathrm{C} \\
30 \mathrm{sec} .\end{array}$ & $\begin{array}{l}72^{\circ} \mathrm{C} \\
30 \mathrm{sec} .\end{array}$ & $\begin{array}{l}72^{\circ} \mathrm{C} \\
7 \mathrm{~min} .\end{array}$ & [12] \\
\hline
\end{tabular}

Statistical Analysis. The experiments related to quantification of anti listerial activity in laboratory media consisted of repeated measurements. The results of these experiments were all analyzed based on ANOVA and were conducted with a significance level of $0.05(\mathrm{P}<0.05)$.

\section{Results And Discussion}

The results of our study revealed 11 L. monocytogenes identified isolates recovered from the collected 60 chilled pork and pork by-products samples with an incidence of $18.3 \%$. This incidence was very near to $(17.42 \%)$ that obtained in the analyzed Korean pork samples [13]., more recent studies also showed close results $(11.5 \%)$ [14], (21.5\%) [15], on the other hand, L. monocytogenes was determined as $34.1 \%$ in pork and pork by-products mostly found in minced pork [16].

As, L. monocytogenes is a facultative intracellular pathogen, so that the principal issue in understanding foodborne listeriosis premises on the role played by virulence factors of L. monocytogenes and how these interact with host susceptibility to result in the observed incidence of disease [17]. The best-characterized $L$. monocytogenes virulence factors are listeriolysin O (LLO), encoded by the hly, and the internalins A and B (InlA and InlB) genes, respectively, which belong to the virulence gene cluster [18].

The present study detected hly gene in 6 out of 11 L. monocytogenes isolates with percentage (54.5\%) as shown in photo (1).

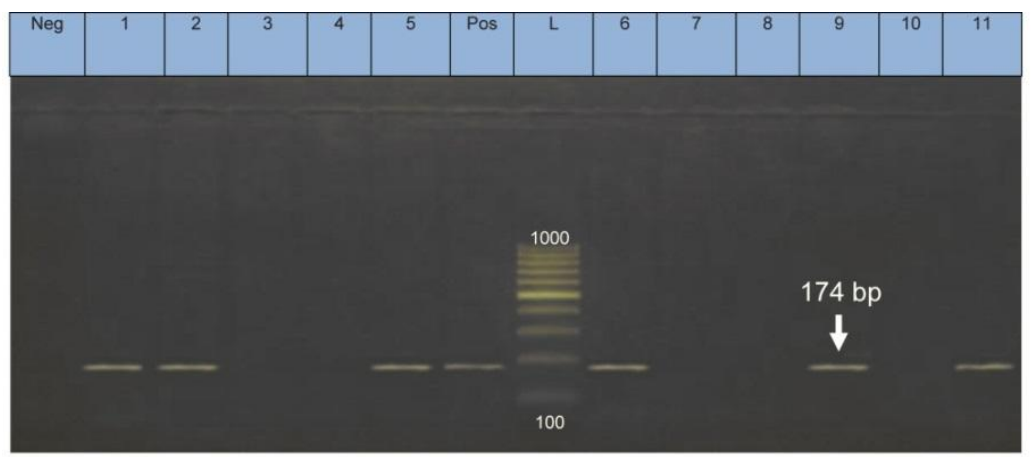

Photo 1: Amplified PCR product of hly gene of 174 bp. Lane L: 1000bp ladder. Lane Neg: negative control. Lane Pos: positive control.

Listeria monocytogenes expresses the surface protein internalin A (InlA), enabling the invasion of human intestinal epithelial cells to cause a severe food-borne diseases [19].

The inlA gene was detected in 7 out of 11 L. monocytogenes isolates with percentage $(63.6 \%)$ as shown in photo (2), while no isolate exhibited amplification of $i n l \mathrm{~B}$.

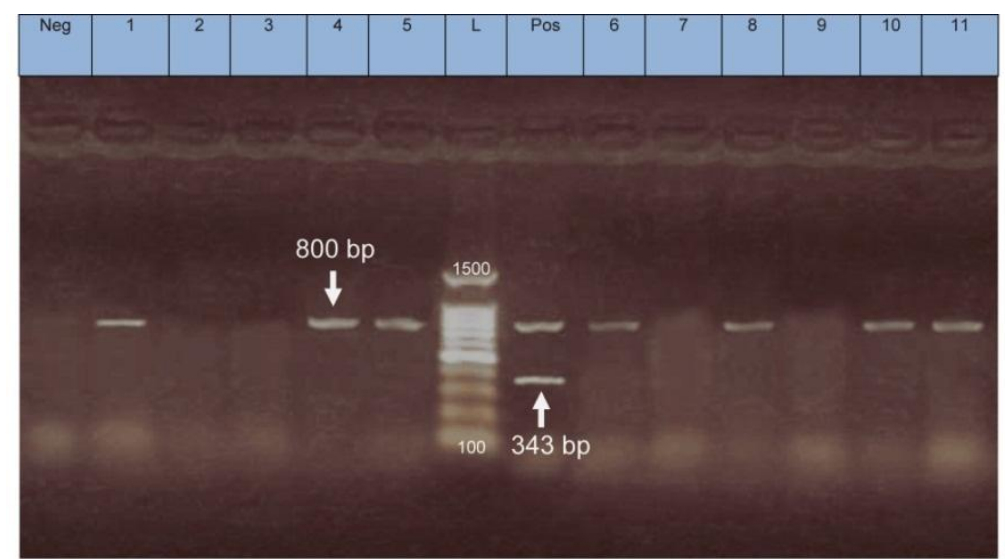

Photo 2: Amplified double PCR products of inlA gene of $800 \mathrm{bp}$ and inlB gene of $343 \mathrm{bp}$. Lane L: 1000bp ladder. Lane Neg: negative control. Lane Pos: positive control. 
$\operatorname{PrfA}$, is considered the master virulence gene regulator of $L$. monocytogenes, which modulates the expression of some operating virulence factors needed for infection by L. monocytogenes [20]. The present study displayed prfA gene in 7 out of 11 L. monocytogenes isolates with percentage (63.6\%) as shown in photo (3).

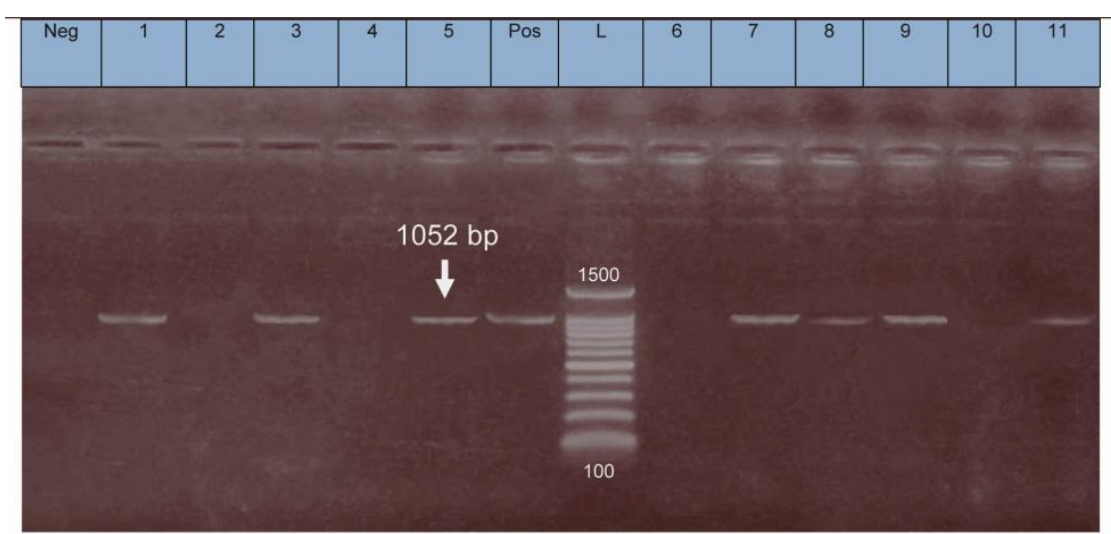

Photo 3: Amplified PCR product of prfA gene of 1052 bp. Lane L: 1000bp ladder. Lane Neg: negative control. Lane Pos: positive control.

The high detection of these virulence genes is usually noticed, recognizing $87.2 \%(68 / 78)$ of the isolates were prfA positive, 97.4\% (76/78) of the isolates were hly positive, 92.3\% (72/78) of the isolates were inlA positive, $100 \%$ (78/78) of the isolates were inlB positive [21]. In contrast, there was another study, which used PCR to test 85 L. monocytogenes pork isolates, only one isolate was found to harbor the hyl gene [22].

Overall, only three isolates showed the presence of the three genes (27.3\%), three isolates also, showed the presence of two genes together (27.3\%), certainly, the obtained result was greatly lower than previous study that demonstrated $42 \%$ of pork $L$. monocytogenes isolates carried the full complement of virulence-associated genes [23], also in another study all thirty L. monocytogenes strains contained virulence genes with expected product size in PCR assay but showed variable expressions of phenotypic activity [24]. Interestingly, the results showed that only 5 isolates exhibited the positive hemolysis zone at sheep blood agar, this could be explained through there was one isolate harbored the hly gene and not harbor the prfA gene so that no expression of this isolate hly gene.

The anti listerial activity results were achieved even the dilution reached $10^{-5}$ but, varied in between the two Lactobacilli species as L. acidophilus was more effective than L. plantarum in a considerable manner. Gram-positive bacteria as $L$. monocytogenes are suggested to be more sensitive to $L$. acidophilus than $L$. plantarum and that may be attributed its ability to produce not only bacteriocin but also, other antimicrobial peptides as acidocin, acidophilin, and lactacin [25].

\section{Conclusion}

The survey of virulence genes among L. monocytogenes isolates obtained from pork byproducts in Egyptian stores tell us that these isolates can represent their pathogenicity and intiate the human disease conditions. Consequently the hygienic precautions should be put in mind to reduce the public health threatening, besides the application of new meat preservatives as adding probiotics which have antilisterial activities.

Conflict of interest: the authors have affirmed that no competing interest exists.

Ethical standards: The manuscript does not contain clinical studies or patient data.

No Acknowledgments

\section{References}

[1]. R. D. Sleator, C. G. M. Gahan, and C. Hill, A postgenomic appraisal of osmotolerance in Listeria monocytogenes. Appl Environ Microbiol 69, 2003, 1-9.

[2]. P.A. Gouws, and I. Liedemann, Evaluation of Diagnostic PCR for the Detection of Listeria monocytogenes in Food Products. Food Tech Biotech 43, 2005, 201-205.

[3]. K. Neuhaus, P. Satorhelyi, K. Schauer, S. Scherer and T. M. Fuchs, Acid shock of Listeria monocytogenes at low environmental temperatures induces prfA, epithelial cell invasion, and lethality towards Caenorhabditis elegans. BMC Genomics, 14, 2013, 285.

[4]. J.A.Vázquez-Boland, M. Kuhn, P. Berche, T. Chakraborty, G. Domínguez-Bernal, W. Goebel, B. González-Zorn, J. Wehland, and J. Kreft, Listeria pathogenesis and molecular virulence determinants. Clin Microbiol Rev. 14(3), 2001, 584-640. Review.

[5]. N.Indrawattana,T. Nibaddhasobon, N. Sookrung, M. Chongsa-Nguan, A. Tungtrongchitr, S. Makino, W. Tungyong, and W. Chaicumpa, Prevalence of Listeria monocytogenes in raw meats marketed in Bangkok and characterization of the isolates by phenotypic and molecular methods. J Health Popul Nutr. 29(1), 2011, 26-38.

[6]. D. Liu, M.L. Lawrence, F.W. Austin, and A.J. Ainsworth, A multiplex PCR for species- and virulence-specific determination of Listeria monocytogenes. Journal of Microbiological Methods 71, 2007, 133-140. 
[7]. S. Kirkan, E.Ö. Göksoy, and O. Kaya, Detection of Listeria monocytogenes by using PCR in Helix pomatia. Turk. J. Vet. Anim. Sci. 30, 2006, 375-380.

[8]. A. Shirazinejad, N. Ismail, and R. Bhat, Lactic acid as a potential decontaminant of selected food borne pathogenic bacteria in Shrimp (Penaeus merguiensis). J. Food born Pathogens and Disease 7, 2010, 1531-1536.

[9]. L. J. Harris, M. A. Daeschel, M. E. Stiles, and T. R. Klaenhammer, Antimicrobial activity of lactic acid bacteria against Listeria monocytogenes. J. Food Prot. 52, 1989, 384-387.

[10]. K. M. J. Swanson, F. F. Busta, E. H. Peterson, and M. G. Johnson, [Colony count methods, 1992, p. 75-95]. In C. Vanderzant, and D. F. Splittstoesser (ed.), compendium of methods for the microbial examination of foods. American Public Health Association, Washington, D.C.

[11]. J.H. Dickinson, R.G. Kroll, and K.A. Grant, The direct application of the polymerase chain reaction to DNA extracted from foods. Letters in Applied Microbiology 20, 1995, 212-216.

[12]. H.G. Deneer, and I. Boychuk, Species-Specific Detection of Listeria monocytogenes by DNA Amplification. Applied And Environmental Microbiology 2, 1991, 606-609.

[13]. Y.C. Choi, S.Y. Cho, B.K. Park, D.H. Chung, D.H. Oh, Incidence and characterization of Listeria spp. from foods available in Korea. J Food Prot. 64(4), 2001, 554-8.

[14]. C. Fang, Y. Shan, T. Cao, Y. Xia, Y. Xin, C. Cheng, H. Song, X. Li, W. Fang, Prevalence and Virulence Characterization of Listeria monocytogenes in Chilled Pork in Zhejiang Province, China. Foodborne Pathog Dis. 13(1), 2016, 8-12.

[15]. D.A. Silva, M.R. Dias, M.V. Cossi, N.P. Castilho, A.C. Camargo, L.A. Nero, Hygiene and Safety in the Meat Processing Environment from Butcher Shops: Microbiological Contamination and Listeria monocytogenes. J Food Prot. 79(4), $2016,628-34$.

[16]. D. Majczyna, D. Białasiewicz, Characteristic of Listeria spp. bacteria isolated from food products. Med Dosw Mikrobiol. 58(2), 2006, 119-26.

[17]. S. Kathariou, Listeria monocytogenes virulence and pathogenicity, a food safety perspective. J Food Prot. 65(11), 2002, 1811-29.

[18]. L.Z. Moreno, R. Paixão, D.D. Gobbi, D.C. Raimundo, T.P. Ferreira, and M.H Matte, Phenotypic and genotypic characterization of atypical Listeria monocytogenes and Listeria innocua isolated from swine slaughterhouses and meat markets. Biomed Res Int. 2014, $2014,742032$.

[19]. M. Kanki, H. Naruse, M. Taguchi, and Y. Kumeda, Characterization of specific alleles in InlA and PrfA of Listeria monocytogenes isolated from foods in Osaka, Japan and their ability to invade Caco-2 cells. Int J Food Microbiol. 211, 2015, 18-22.

[20]. J.A. Good, C. Andersson, S. Hansen, J. Wall, K.S. Krishnan, A. Begum, C. Grundström, M.S. Niemiec, K. Vaitkevicius, and J. Johansson, Attenuating Listeria monocytogenes Virulence by Targeting the Regulatory Protein PrfA. Cell Chem Biol. 23(3), 2016, 404-14.

[21]. Y. Yang, P. Fu, Y.C. Guo, X.Y. Pei, and X.M. Liu, Virulent gene prevalence of foodborne Listeria monocytogenes in China in 2005. Zhonghua Yu Fang Yi Xue Za Zhi. 44(12), 2010, 1097-101.

[22]. M.D. Ndahi, J.K. Kwaga, M. Bello, J. Kabir, V.J. Umoh, S.E. Yakubu, and A.J. Nok, Prevalence and antimicrobial susceptibility of Listeria monocytogenes and methicillin-resistant Staphylococcus aureus strains from raw meat and meat products in Zaria, Nigeria. Lett Appl Microbiol. 58(3), 2014, 262-9.

[23]. D. Meloni, F. Piras, A. Mureddu, F. Fois, S.G. Consolati, S. Lamon, and R. Mazzette, Listeria monocytogenes in five Sardinian swine slaughterhouses: prevalence, serotype, and genotype characterization. J Food Prot. 76(11), 2013, $1863-7$.

[24]. Z.W. Jaradat, G.E. Schutze, A.K. Bhunia, Genetic homogeneity among Listeria monocytogenes strains from infected patients and meat products from two geographic locations determined by phenotyping, ribotyping and PCR analysis of virulence genes. Int $J$ Food Microbiol. 76(1-2), 2002, 1-10.

[25]. M. Millette, F.M. Luquet, and M. Lacroix, In vitro growth control of selected pathogens by Lactobacillus acidophilus and Lactobacillus casei fermented milk. Lett Appl Microbiol. 44(3), 2007, 314-9. 